\title{
NF1 microdeletion syndrome: case report of two new patients
}

\author{
Gregorio Serra ${ }^{1}$, Vincenzo Antona ${ }^{1}$, Giovanni Corsello ${ }^{1}$, Federico Zara ${ }^{2}$, Ettore Piro ${ }^{1 *}$ (i) and Raffaele Falsaperla ${ }^{3}$
}

\begin{abstract}
Background: 17q11.2 microdeletions, which include the neurofibromatosis type 1 (NF1) gene region, are responsible for the NF1 microdeletion syndrome, observed in 4.2\% of all NF1 patients. Large deletions of the NF1 gene and its flanking regions are associated with a more severe NF1 phenotype than the NF1 general population.

Case presentation: We hereby describe the clinical and molecular features of two girls (aged 2 and 4 years, respectively), with non-mosaic atypical deletions. Patient 1 showed fifteen café-au-lait spots and axillary freckling, as well as a Lisch nodule in the left eye, strabismus, high-arched palate, malocclusion, severe kyphoscoliosis, bilateral calcaneovalgus foot, mild generalized hypotonia, hyperactivity and deficits of speech-related abilities. NF1 genomic rearrangements through multiplex ligation-dependent probe amplification (MLPA) detected an heterozygous deletion of the whole NF1 gene. Array comparative genomic hybridization (a-CGH) analysis defined a 17q11.2 deletion of about $1 \mathrm{Mb}$ (breakpoints at positions 29,124,299 and 30,151,654), which involved different genes (partially CRLF3, ATAD5, TEFM, ADAP2, RNF135, OMG, EVI2B, EVI2A, RAB11FIP4), including NF1. Patient 2 showed growth and developmental delay, supravalvular pulmonary stenosis, twenty-five café-au-lait spots, axillary freckling, craniofacial dysmorphic features, short neck with pterygium, limb abnormalities and foci of neural dysplasia on brain magnetic resonance imaging (MRI). MLPA detected an heterozygous deletion of NF1, which was detailed by a-CGH indicating the positions 29, 124,299 and 30,326,958 as its breakpoints, and which included aside from the genes deleted in Patient 1 also COPRS, UTP6 and partially SUZ12. Fluorescent in situ hybridization (FISH) analysis of the parents documented a de novo origin of the deletions in both cases.
\end{abstract}

Conclusions: The present report will likely provide further insights and a better characterization of NF1 microdeletion syndrome.

Keywords: NF1 gene, Atypical deletion, Genotype-phenotype correlation, Contiguous gene syndrome, MLPA

\section{Background}

Neurofibromatosis type 1 (NF1; MIM\#162200) is a neurogenetic disorder with a birth prevalence estimated around 1:2500 [1]. NF1 shows an autosomal dominant pattern of inheritance and wide phenotypical variability. Café-au-lait spots (CALs), cutaneous and/or subcutaneous neurofibromas (CNFs/SCNFs), skinfold freckling, skeletal abnormalities and Lisch nodules of the iris are its main clinical features. NF1 patients have an increased risk of learning and intellectual disabilities as well as tumors of the nervous system and other organs [1]. NF1 gene maps on chromosome 17q11.2. Microdeletions of

\footnotetext{
* Correspondence: ettore.piro@unipa.it

'Department of Sciences for Health Promotion and Mother and Child Care

"G. D'Alessandro", University of Palermo, Palermo, Italy

Full list of author information is available at the end of the article
}

this region are responsible for NF1 microdeletion syndrome, observed in $4.2 \%$ of all NF1 patients. Large deletions of NF1 and its flanking regions have been associated with more severe phenotype than NF1 general population. Four types (1, 2, 3 and atypical) of such large NF1 deletions have been reported so far, with differences in size, breakpoint location, number of genes deleted and somatic mosaicism [2]. Type-1 is the most frequent (70-80\%), while $8-10 \%$ are atypical [3]. In the present study we report on the clinical and molecular features of two patients with non-mosaic atypical NF1 deletions, in order to give further insights and a better characterization of NF1 microdeletion syndrome.

(c) The Author(s). 2019 Open Access This article is distributed under the terms of the Creative Commons Attribution 4.0 International License (http://creativecommons.org/licenses/by/4.0/), which permits unrestricted use, distribution, and reproduction in any medium, provided you give appropriate credit to the original author(s) and the source, provide a link to the Creative Commons license, and indicate if changes were made. The Creative Commons Public Domain Dedication waiver (http://creativecommons.org/publicdomain/zero/1.0/) applies to the data made available in this article, unless otherwise stated. 


\section{Case presentation}

\section{Patient 1}

This 4-year-old female was the first born, at 35 weeks of gestation, by vaginal delivery. Family and pregnancy histories were uneventful. At birth her weight was 2400 g (62nd percentile), length $45 \mathrm{~cm}$ (46th percentile), and occipitofrontal circumference (OFC) $31.3 \mathrm{~cm}$ (41st percentile). At the time of the presentation, her weight was $14.700 \mathrm{~kg}$ (25th percentile), height $104 \mathrm{~cm}$ (50th to 75th percentile) and OFC $49.5 \mathrm{~cm}$ (25th to 50th percentile). She had fifteen café-au-lait spots (mainly located in the nuchal and gluteal regions, the left elbow and the posterior surface of the right lower limb) and axillary freckling (Fig. 1), as well as a Lisch nodule in the left eye, strabismus, high-arched palate and malocclusion. Severe kyphoscoliosis and bilateral calcaneovalgus foot were also noted.

The neuropsychiatric evaluation, by Wechsler Preschool and Primary Scale of Intelligence (WPPSI) [4] and Peabody Picture Vocabulary Test-III (PPVT-III), showed deficits of speech-related abilities (Table 1).

Mild generalized hypotonia, dysgraphia (she went to primary school and was evaluated after the full school reading, writing and calculation skills attained by the first four months) and hyperactivity completed her

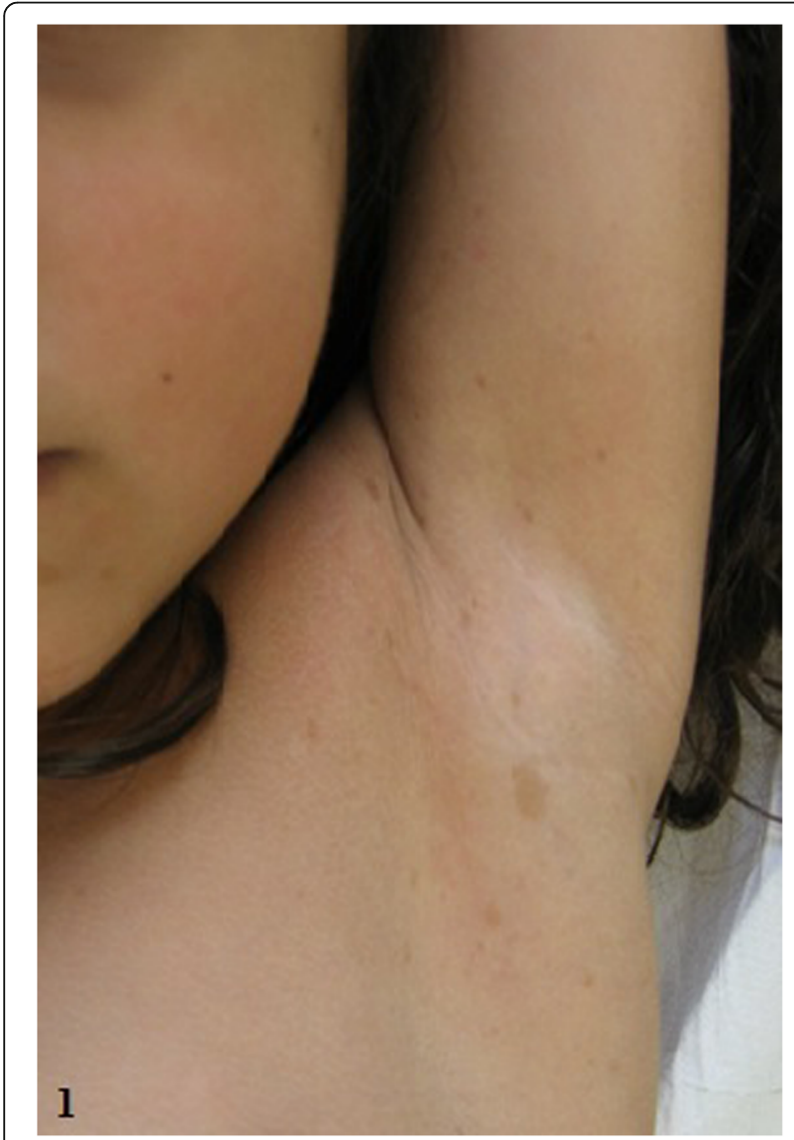

Fig. 1 Patient 1: axillary frackling
Table 1 Neuropsychiatric evaluation. Patient 1 profile has been evaluated by WPPSI-IV (Wechsler Preschool and Primary Scale of Intelligence for children younger than $6 \mathrm{yr}$ of age)

WPPSI-IV (Wechsler Intelligence Scale for children)

\begin{tabular}{ll}
\hline Total IQ & 88 (within normal value) \\
\hline Verbal IQ & 71 (low value) \\
Performance IQ & 122 (within normal value) \\
\hline
\end{tabular}

clinical profile at the age of 6 . Brain MRI and US heart evaluation showed no abnormalities.

No pathogenic mutations were revealed by molecular analysis of the NF1 and SPRED1 genes, through amplification of the coding regions and the flanking intronic sequences and sequencing of the amplified regions. Then, NF1 genomic rearrangements through multiplex ligation-dependent probe amplification (MLPA) were performed, and the heterozygous deletion of the whole NF1 gene was detected. Array comparative genomic hybridization (a-CGH) analysis (100-150 Kb resolution, genomic assembly GRCh37.p13) defined a 17q11.2 deletion of about $1 \mathrm{Mb}$, and identified the breakpoints at positions 29,124,299 and 30,151,654. The deleted region involved different genes (partially CRLF3, ATAD5, TEFM, ADAP2, RNF135, OMG, EVI2B, EVI2A, RAB11FIP4), including NF1. The rearrangement was confirmed by fluorescent in situ hybridization (FISH) (Additional file 1).

\section{Patient 2}

This 2-year-8-month-old female was the second born by vaginal delivery, from healthy non-consanguineous parents, at $37^{+5}$ weeks of gestation after an uneventful pregnancy. At birth her weight was $2860 \mathrm{~g}$ (34th percentile), length 45 $\mathrm{cm}$ (4th percentile), OFC $31 \mathrm{~cm}$ (3rd percentile). At 8 months of age her weight, length and OFC were $6670 \mathrm{~g}$ (3rd to 10th percentile), 66 (3rd to 10th percentile) and 42 $\mathrm{cm}$ (3rd to 10th percentile), respectively. At her first neurodevelopmental examination at 18 months old, a global developmental delay was observed. EEG was normal, while US heart evaluation showed mild supravalvular pulmonary stenosis (pressure gradient $<50 \mathrm{mmHg}$ ).

At the age of 2, because of her growth delay, cardiomyopathy and dysmorphic features, sequencing of the genes PTPN11, RAF1, BRAF1, MEK1/2, KRAS, SOS1 and $S H O C 2$ were performed. No abnormalities were detected. Plasma amino acid pattern, plasma and urine levels of glycosaminoglycans, acylcarnitine profile and urine organic acids were normal.

At the time of the presentation, her weight was 10.160 $\mathrm{kg}(<10$ th percentile), height $83 \mathrm{~cm}(<10$ th percentile) and OFC $47.3 \mathrm{~cm}(<10$ th percentile). She had twenty-five café-au-lait spots (mainly located in the anterior thoracic-abdominal region, upper back, posterior surface of the left thigh and proximal extremity of the right 
lower limb) and axillary freckling, as well as craniofacial dysmorphic features (broad forehead, dysplasic and lowset ears with thick helix, synophris, receding orbital roof with exophthalmos, hypertelorism, depressed nasal bridge, bulbous nose, malar hypoplasia, long and prominent philtrum, thick lips) and short neck with pterygium. Pectus excavatum, wide-spaced nipples, supernumerary areola, diastasis recti abdominis with prominent abdomen were also noted (Fig. 2). Short hands and feet, clinodactyly of the 5th finger, deep palmar creases and bilateral genu valgum and pes plano-valgus were observed (Fig. 2). Brain

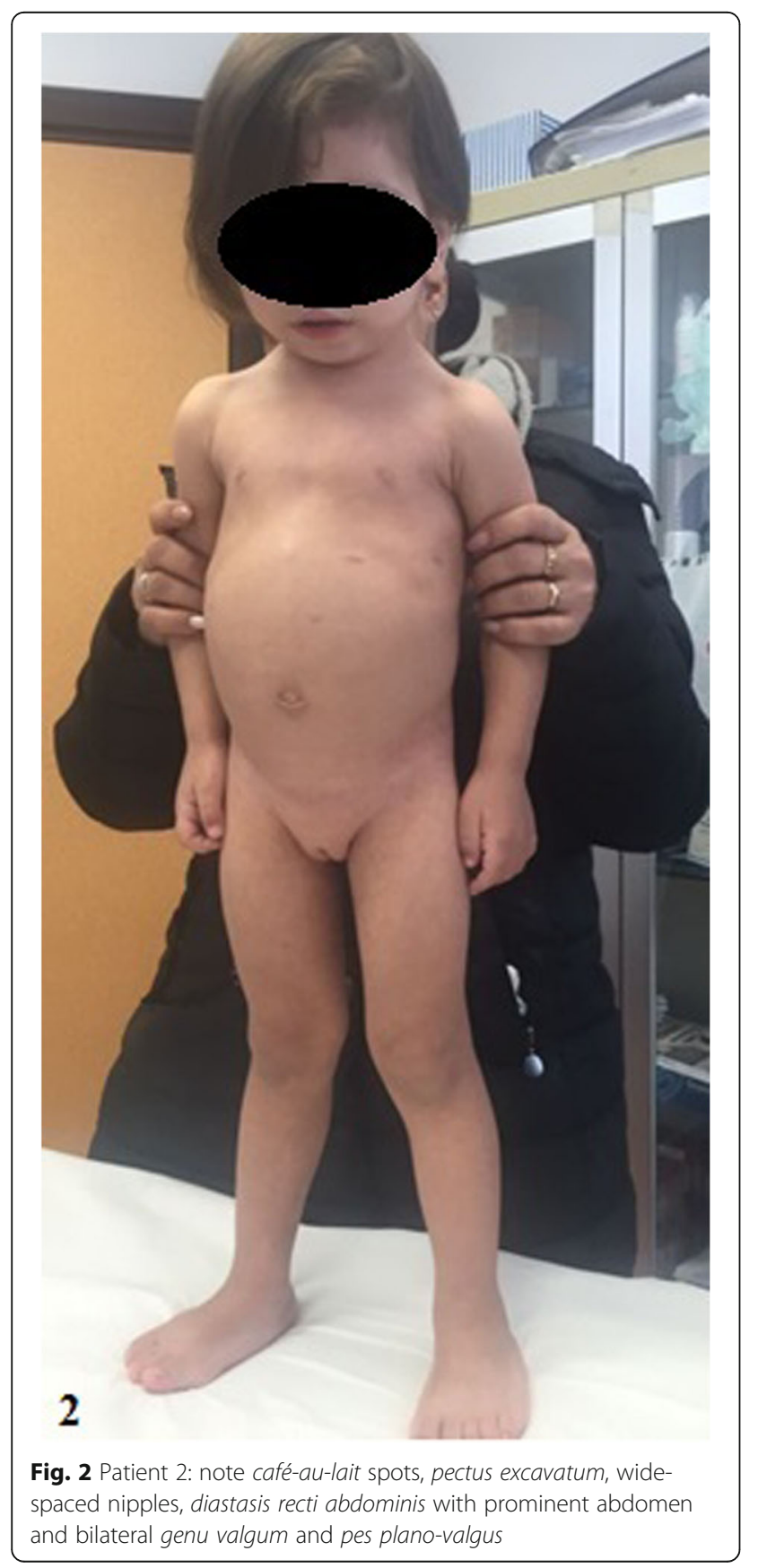

MRI revealed corpus callosum hypoplasia, T2 hyperintensities near the fourth ventricle, periventricular hyperintensities and a hyperintense nodule in the left thalamus, which were thought as foci of neural dysplasia with defect of myelination.

During a follow-up visit her cognitive profile was evaluated by WPPSI-IV for children younger than $6 \mathrm{yr}$ of age, leading to the diagnosis of a mild intellectual disability (Table 2).

Molecular analysis of the genes NF1 and SPRED1, through amplification of the coding regions and the flanking intronic sequences and sequencing of the amplified regions did not detect any pathogenic mutations. Therefore, NF1 genomic rearrangements through MLPA were performed, and identified an heterozygous deletion of NF1. a-CGH (100-150 Kb resolution, genomic assembly GRCh37.p13) detailed a deletion of $1.2 \mathrm{Mb}$, and indicated the positions $29,124,299$ and $30,326,958$ as the breakpoints of the deletion, which included aside from the genes deleted in Patient 1 also COPRS, UTP6 and partially SUZ12. FISH was performed in both subjects aside from peripheral blood leucocytes also on buccal swab DNA, confirming the rearrangement also in peripheral tissue and ruling out somatic mosaicism (Additional file 1).

\section{Familial gene analysis}

In both children and their parents, all exonic and intronic regions of NF1 gene and its flanking regions were amplified through polymerase chain reaction (PCR), and the products were purified and directly sequenced. FISH analysis revealed in both cases a de novo origin of rearrangements.

\section{Discussion and conclusions}

17q11.2 microdeletions, encompassing NF1 gene, are responsible for NF1 microdeletion syndrome [5], which include dysmorphic features, neurodevelopmental delay, cardiovascular defects, overgrowth, a higher tumor burden and earlier onset of benign neurofibromas and malignant peripheral nerve sheath tumors (MPNST)/ other malignancies [2]. It represents $4.2 \%$ of all NF1 patients. The first 17q11.2 microdeletion patient was reported in 1992. Since then, more than 150 subjects have been described [6].

Table 2 Neuropsychiatric evaluation. Patient 2 profile has been evaluated by WPPSI-IV (Wechsler Preschool and Primary Scale of Intelligence for children younger than $6 \mathrm{yr}$ of age)

WPPSI-IV (Wechsler Intelligence Scale for children)

\begin{tabular}{ll}
\hline Total IQ & 55 (low value) \\
\hline Verbal IQ & 64 (low value) \\
Performance IQ & 61 (low value) \\
\hline
\end{tabular}


Four types of large NF1 deletion have been identified (1, 2,3 and atypical), recognizable by size, breakpoint location, number of genes deleted and somatic mosaicism [2].

Type-1 NF1 deletion patients, whose anomaly encompasses $1.4 \mathrm{Mb}$ and comprises 14 protein-coding genes and 4 microRNA genes, are the most frequent (70-80\%). Type-2 extends for $1.2 \mathrm{Mb}$ and depends on hemizygosity of 13 genes, sparing $L R R C 37 B$ (about $10 \%$ ). Type-3 is very rare (1-4\%), spanning $1.0 \mathrm{Mb}$ for a total of 9 genes [3]. Atypical deletions do not show recurrent breakpoints and are heterogeneous in size and genes deleted $(8-10 \%)$ [2]. Unlike the well documented clinical phenotype of type-1 NF1 deletions, a more detailed characterization of patients with atypical NF1 deletions is lacking.

Here we have presented two de novo non-mosaic atypical deletions detected by MLPA, and defined through a-CGH, in two girls with developmental delay and dysmorphic features of variable clinical expressivity and severity.

No pathogenic mutations were firstly revealed by molecular analysis of the NF1 and SPRED1 genes, through amplification of the coding regions and the flanking intronic sequences and sequencing of the amplified regions. However, these tests do not allow the identification of genomic rearrangements like gain or losses of genetic material. Therefore, NF1 genomic rearrangements through multiplex ligation-dependent probe amplification (MLPA) were performed, and the heterozygous deletion of the whole NF1 gene was detected.
The deletions of our probands cannot be classified as type 1,2 or 3 , because the breakpoints do not harbor within the low-copy repeats which are recurrent for such deletions (NF1-REPa, b and c), but outside of them (Fig. 3). Particularly, present deletions do not or partially encompass genes typically involved in such rearrangements (i.e. CRLF3, SUZ12, LRRC37B in the case of type1 and 2), as well as affect genes that are usually spared (i.e. CRLF3, ATAD5, TEFM, ADAP2 and RNF135 in type-3) (Fig. 3, modified from Kehrer-Sawatzki et al. [2]).

a-CGH profiles show the three types of recurrent (typical) deletions (type-1, 2 and 3) included within the low-copy repeats (NF1-REPa and c), compared with our Patient 1 and 2 atypical deletions. Cen centromeric direction, tel telomeric direction.

Both children were clinically evaluated according to the criteria of National Institutes of Health (NIH) for NF1 [7], revised by Gutmann et al. [8]. They fulfilled two criteria ( $\geq 6$ CALs and axillary/inguinal freckling for both) of the seven established for NF1 diagnosis (including also $\geq 2 \mathrm{CNFs} / \mathrm{SCNFs}$ or 1 plexiform neurofibroma, typical bone lesions, $\geq 2$ Lisch nodules of the iris, optic nerve glioma, an affected first degree relative).

The association between wide NF1 deletions and a phenotype which is more severe than the NF1 general population, presenting a higher prevalence of learning disabilities, dysmorphic features and increased tumor risk, has been reported [9] and it is consistent with our experience. Specifically, type 1 microdeletion phenotype

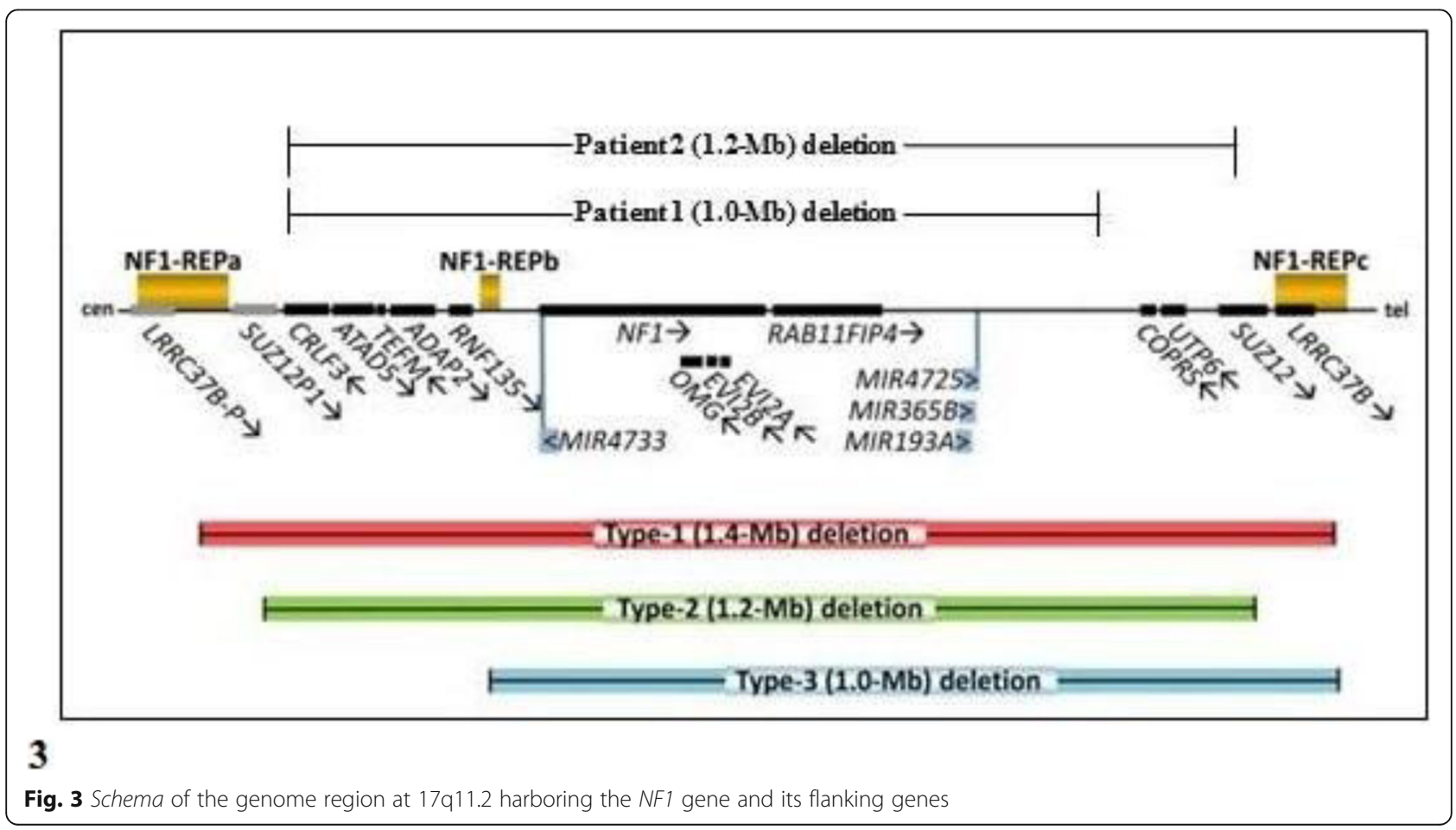


includes facial dysmorphic features, overgrowth/tall-forage stature, cognitive delay, scoliosis, bone cysts, large hands and feet, hyperflexibility of joints and muscular hypotonia [2]. The clinical manifestations are related to both the number and type of deleted genes, which in turn has an influence on the genotype-phenotype interaction. Indeed, 17q11.2 microdeletion has been considered as a contiguous gene syndrome, in which the involvement of some of the genes contiguous to NF1 may modify the phenotype of patients [3]. This may explain the wide clinical variability among microdeletion patients including the two patients here described, which are located at the extremes of the phenotypic spectrum. Comparing the clinical features of our two patients with type-1 NF1 deletions, a partial phenotypic overlap may be observed. In particular, facial dysmorphisms, neurodevelopmental delay, hypotonia, cardiovascular defects (only in Patient 2), hands/feet anomalies, and kyphoscoliosis (only in Patient 1). Conversely, overgrowth/tall-for-age stature and high tumor load (significantly more frequent in non-mosaic type-1 and 2) are currently absent in our probands, although they cannot be excluded over time. As described above, Patient 1 phenotype is milder than Patient 2 (Table 3).

Haploinsufficiency of genes within the critical interval could modify the phenotype of present children. To estimate the likely effect of the deleted genes, the probability of loss-of-function (LoF) intolerance should be considered, differentiating genes in LoF intolerant or tolerant [2]. Specifically, 5 genes (CRLF3, ATAD5, RAB11FIP4, SUZ12 and LRRC37B) were predicted to be LoF intolerant [2], which means that they could have clinical consequences if present in one copy [5]; 4 of them (2 partially) are deleted in our subjects.

RNF135 (ring finger protein 135, MIM:611358), encodes an E3 ubiquitin ligase. This protein contains a ring finger domain, which may be involved in protein-protein and protein-DNA interactions. The gene, expressed in many different tissues (including the cortex and cerebellum), is deleted in both probands. It could be responsible for the dysmorphic facial features of our patients, in agreement with literature data [2]. Its haploinsufficiency may also contribute to the reduced cognitive abilities observed in NF1 microdeletion patients [2], and then be related to the specific developmental profile of our children. Furthermore, its mutations have been recently documented to be linked to overgrowth and glioblastoma cells in vivo and in vitro, as well as autism, suggesting for patients carrying its deletion, an even more individualized and careful neuropsychiatric and oncologic follow-up.

Similarly, also abnormalities of OMG (oligodendrocyte myelin glycoprotein, MIM:164345), deleted in both of our subjects, seem to be involved in autism spectrum disorders, schizophrenia and intellectual disability [10].
Its transcribed protein plays a key role in the early stages of brain development, likely regulating neurogenesis. Indeed, it belongs to myelin-associated inhibitor proteins (MAIPs) which are central nervous system regeneration inhibitors. Since MAIPs are involved in regulating synapses, abnormal expression of these proteins may cause intellectual disability and other brain disorders [2].

Mutations of ADAP2 (ArfGAP with dual PH domains 2, MIM:608635) may contribute to the cardiovascular malformations noted in patients with NF1 microdeletions $[11,12]$. The gene is highly expressed during early stages of cardiac embryogenesis. The protein encoded by this gene binds beta-tubulin and increases the stability of microtubules. Specifically, cytoskeletal defects of myocytes, due to such altered proteins, may lead to the cardiovascular malformations observed in NF1 microdeletion patients. Although deleted in both probands, cardiac involvement given by supravalvular pulmonary stenosis is present only in Patient 2. This could be explained since SUZ12 and UTP6, expressed during the development of human heart and deleted only in Patient 2, may contribute either cooperatively or additively to the cardiomyopathy.

As suggested by definition, atypical large NF1 deletions do not have recurrent breakpoints and are heterogeneous in size and genes deleted [2]. However, the extent of the deletion may be important in the context of genotypephenotype relationships in such patients. Indeed, our study suggests that these subjects may exhibit most of the clinical features reported in germline type-1 NF1 deletions. A severe form of the disease is not limited, then, to type-1 deletions, but it may also occur in non-mosaic atypical ones, depending on the extent of the rearrangement and the genes deleted.

Patient 1 shows a neurodevelopmental profile characterized by language disorder without cognitive impairment, and mild craniofacial dysmorphisms (high-arched palate). We propose a correlation between the smaller number of genes/regulatory elements of such deletion and milder clinical manifestations. Therefore, although the clinical characteristics of NF1 microdeletion patients are usually more severe, this particular form of neurofibromatosis should not be excluded "a priori" even in the presence of patients who show a mild clinical picture (Patient 1), especially in pediatric age, when many of the typical features of the syndrome (i.e. CNFs or SCNFs, MPNST, etc. ...) are not yet manifest. Conversely, the more severe clinical picture of Patient 2 may be due to involvement of the genes COPRS, UTP6 and SUZ12 (the latter predicted to be LoF intolerant). COPRS (coordinator of PRMT5 and differentiation stimulator) is widely expressed in human tissues, mostly in testis and brain [13], and has been associated with overgrowth as well as learning disabilities and dysmorphic features of NF1 microdeletion patients. It encodes an adaptor protein 
Table 3 Comparison of the clinical and genetic features in both patients

\begin{tabular}{|c|c|c|}
\hline & Patient 1 & Patient 2 \\
\hline $\begin{array}{l}\text { Sex/ first } \\
\text { examination } \\
\text { age (years) }\end{array}$ & $F / 4$ & $\mathrm{~F} / 2$ and 8 months \\
\hline $\begin{array}{l}\text { Café-au-lait } \\
\text { spots }\end{array}$ & 15 & 25 \\
\hline $\begin{array}{l}\text { Axillary } \\
\text { freckling }\end{array}$ & $+($ Fig. 1) & + \\
\hline Lisch nodules & 1 , in the left eye & - \\
\hline $\begin{array}{l}\text { Craniofacial } \\
\text { dysmorphic } \\
\text { features }\end{array}$ & high-arched palate & $\begin{array}{l}\text { broad forehead } \\
\text { dysplasic and low-set ears } \\
\text { with thick helix } \\
\text { synophris } \\
\text { receding orbital roof with } \\
\text { exophthalmos } \\
\text { hypertelorism } \\
\text { depressed nasal bridge } \\
\text { bulbous nose } \\
\text { malar hypoplasia } \\
\text { long and prominent } \\
\text { philtrum thick lips }\end{array}$ \\
\hline Pterygium colli & - & + \\
\hline $\begin{array}{l}\text { Thoracic } \\
\text { abnormalities }\end{array}$ & - & $\begin{array}{l}\text { Pectus excavatum } \\
\text { wide-spaced nipples } \\
\text { supernumerary areola (Fig. 2) }\end{array}$ \\
\hline $\begin{array}{l}\text { Abdominal wall } \\
\text { abnormalities }\end{array}$ & - & $\begin{array}{l}\text { diastasis recti abdominis with } \\
\text { prominent abdomen (Fig. 2) }\end{array}$ \\
\hline $\begin{array}{l}\text { Oral } \\
\text { abnormalities }\end{array}$ & malocclusion & - \\
\hline $\begin{array}{l}\text { Bone } \\
\text { abnormalities }\end{array}$ & $\begin{array}{l}\text { severe kyphoscoliosis } \\
\text { bilateral calcaneovalgus } \\
\text { foot }\end{array}$ & $\begin{array}{l}\text { short hands/feet } \\
\text { clinodactyly of the } 5 \text { th finger } \\
\text { deep palmar creases } \\
\text { bilateral genu valgum } \\
\text { andpes plano-valgus } \\
\text { (Fig. 2) }\end{array}$ \\
\hline $\begin{array}{l}\text { Muscular } \\
\text { abnormalities }\end{array}$ & $\begin{array}{l}\text { hypotonia/muscular } \\
\text { hypotrophy }\end{array}$ & - \\
\hline $\begin{array}{l}\text { Intellectual } \\
\text { disability }\end{array}$ & - & mild intellectual disability \\
\hline $\begin{array}{l}\text { Cardiovascular } \\
\text { defects }\end{array}$ & - & $\begin{array}{l}\text { supravalvular pulmonary } \\
\text { stenosis }\end{array}$ \\
\hline $\begin{array}{l}\text { Developmental } \\
\text { delay }\end{array}$ & speech impairment & global developmental delay \\
\hline $\begin{array}{l}\text { Brain MR } \\
\text { abnormalities }\end{array}$ & - & $\begin{array}{l}\text { corpus callosum hypoplasia } \\
\text { T2 hyperintensities near the } \\
\text { fourth ventricle } \\
\text { periventricular } \\
\text { hyperintensities } \\
\text { hyperintense nodule in the } \\
\text { left thalamus }\end{array}$ \\
\hline $\begin{array}{l}\text { Genetic test } \\
\text { result (CGHa - } \\
\text { FISH } \\
\text { confirmation) }\end{array}$ & $\begin{array}{l}\text { 17q11.2 deletion (1 Mb) } \\
\text { - partially CRLF3, ATAD5, } \\
\text { TEFM, ADAP2, RNF135, } \\
\text { OMG, EVI2B, EVI2A, } \\
\text { RAB11FIP4 (position 29, } \\
\text { 124,299 to 30,151,654) }\end{array}$ & $\begin{array}{l}\text { 17q11.2 deletion (1.2 Mb) - } \\
\text { partially CRLF3, ATAD5, TEFM, } \\
\text { ADAP2, RNF135, OMG, EVI2B, } \\
\text { EVI2A, RAB11FIP4, COPRS, } \\
\text { UTP6 and partially SUZ12 } \\
\text { (position 29,124,299 to 30, } \\
326,958 \text { ) }\end{array}$ \\
\hline
\end{tabular}

binding to protein-arginine methyltransferase 5 (PRMT5) and to hystone H4. Such COPRS-PRMT5 complex regulates cell differentiation, and is then involved in tumorigenesis. UTP6 (UTP6 small subunit processome component) and SUZ12 (SUZ12 polycomb repressive complex 2 subunit, MIM:606245) may be associated with congenital heart defects [11], and together with COPRS they may contribute to the increased tumour risk associated with NF1 microdeletion [14]. However, although their haploinsufficiency could exert additive negative effects on the phenotype of Patient 2, no conclusions can be drawn yet with regards to their role in the specific phenotype. The limited number of microdeletion patients together with the imprecise definition of their boundaries, especially in atypical deletions, make it quite difficult to establish reliable genotype-phenotype correlations [15]. Then, genetic analysis, not always performed in the past, is actually a diagnostic step in characterizing a patient with or suspected of NF1. In case of microdeletion, a-CGH is an important tool to finely define deletions. Although NF1 diagnosis is still based on clinical criteria, information obtained from genetic analysis can be an important instrument to plan a more individualized clinical follow-up.

Phenotypical variability is observed in NF1 microdeletion patients, even in cases of identical germline deletions [16]. Hence, the phenotype associated with NF1 microdeletions is likely to be influenced by genetic elements such as the expression variations of non-deleted genes and/or the presence of feature-specific modifier genes. In addition, epigenetic factors such as the expression of the wild-type alleles of the genes present in one copy could play a role. Environmental factors may also interact with both of them. An extended comparative analysis of a larger number of age-matched patients with additional overlapping features may allow a more precise clinical and genomic characterization [17]. This is also useful to achieve a better genotype-phenotype correlation.

\section{Supplementary information}

Supplementary information accompanies this paper at https://doi.org/10. 1186/s13052-019-0718-7.

Additional file 1. Timelines of the clinical cases.

\section{Abbreviations}

a-CGH: array comparative genomic hybridization; CALs: Café-au-lait spots; CNFs/SCNFs: Cutaneous/subcutaneous neurofibromas; EEG: Electroencephalogram; FISH: Fluorescence in situ hybridization; MLPA: Multiplex ligation-dependent probe amplification; MPNST: Malignant peripheral nerve sheath tumors; MRI: Magnetic resonance imaging; NF1: Neurofibromatosis type 1; NIH: National Institutes of Health; OFC: Occipitofrontal circumference; PCR: Polymerase chain reaction; PPVTIII: Peabody Picture Vocabulary Test-III; US: Ultrasound; WPPSI: Wechsler Preschool and Primary Scale of Intelligence 


\section{Authors' contributions}

GS collected clinical data and drafted the manuscript. VA performed clinical and genetic counseling. GC conceptualized the study, revised the manuscript and gave final approval of the version to be submitted. FZ contributed to acquisition and interpretation of genetic data. EP performed neurological and developmental assessment. RF contributed to interpretation of neurological and developmental data, revised the manuscript and gave final approval of the version to be submitted. All authors read and approved the final manuscript.

\section{Funding}

No funding was granted for this research.

\section{Availability of data and materials}

The datasets used and/or analyzed during the current study are available from GC on reasonable request.

\section{Ethics approval and consent to participate}

The study was approved by the Mother and Child Department of the University of Palermo (Palermo, Italy); at the time of each recording, the parents of both patients signed an informed consent. All procedures performed in this study were in accordance with the ethical standards of the institutional and/or national research committee, and with the 1964 Helsinki declaration and its later amendments or comparable ethical standards.

\section{Consent for publication}

Not applicable.

\section{Competing interests}

The authors declare that they have no competing interests.

\section{Author details}

'Department of Sciences for Health Promotion and Mother and Child Care "G. D'Alessandro", University of Palermo, Palermo, Italy. ${ }^{2}$ Laboratory of Neurogenetics and Neuroscience, Institute G. Gaslini, Genoa, Italy. ${ }^{3}$ Unit of Pediatrics and Pediatric Emergency, University Hospital "Policlinico-Vittorio Emanuele", Catania, Italy.

Received: 7 April 2019 Accepted: 16 September 2019

Published online: 08 November 2019

\section{References}

1. Corsello G, Antona V, Serra G, Zara F, Giambrone C, Lagalla L, Piccione M, Piro E. Clinical and molecular characterization of 112 single-center patients with Neurofibromatosis type 1. Ital J Pediatr. 2018;44(1):45.

2. Kehrer-Sawatzki H, Mautner VF, Cooper DN. Emerging genotype-phenotype relationships in patients with large NF1 deletions. Hum Genet. 2017;136(4): 349-76.

3. Vogt J, Nguyen R, Kluwe L, Schuhmann M, Roehl AC, Mußotter T, Cooper DN, Mautner VF, Kehrer-Sawatzki H. Delineation of the clinical phenotype associated with non-mosaic type-2 NF1 deletions: two case reports. J Med Case Rep. 2011;5:577.

4. van der Steene G, Bos A. Wechsler preschool and primary scale of intelligence (Dutch version), manual. Lisse, The Netherlands: Swets, Zeitlinger BV; 1997.

5. Xie B, Fan X, Lei Y, Chen R, Wang J, Fu C, Yi S, Luo J, Zhang S, Yang Q, Chen $\mathrm{S}$, Shen Y. A novel de novo microdeletion at 17q11.2 adjacent to NF1 gene associated with developmental delay, short stature, microcephaly and dysmorphic features. Mol Cytogenet. 2016;9:41.

6. Mensink KA, Ketterling RP, Flynn HC, Knudson RA, Lindor NM, Heese BA, Spinner RJ, Babovic-Vuksanovic D. Connective tissue dysplasia in five new patients with NF1 microdeletions: further expansion of phenotype and review of the literature. J Med Gen. 2006;43(2):e8.

7. Neurofibromatosis. Conference statement. National Institutes of Health consensus development conference. Arch Neurol. 1988;45(5):575-8.

8. Gutmann DH, Aylsworth A, Carey JC, Korf B, Marks J, Pyeritz RE, Rubenstein A, Viskochil D. The diagnostic evaluation and multidisciplinary management of neurofibromatosis 1 and neurofibromatosis 2. JAMA. 1997;278(1):51-7.

9. De Raedt T, Brems H, Wolkenstein P, Vidaud D, Pilotti S, Perrone F, Mautner $V$, Frahm S, Sciot R, Legius E. Elevated risk for MPNST in NF1 microdeletion patients. Am J Hum Genet. 2003;72(5):1288-92.
10. Bernardinelli Y, Nikonenko I, Muller D. Structural plasticity: mechanisms and contribution to developmental psychiatric disorders. Front Neuroanat. 2014;8:123.

11. Venturin M, Bentivegna A, Moroni R, Larizza L, Riva P. Evidence by expression analysis of candidate genes for congenital heart defects in the NF1 microdeletion interval. Ann Hum Genet. 2005;69:508-16.

12. Venturin M, Carra S, Gaudenzi G, Brunelli S, Gallo GR, Moncini S, Cotelli F, Riva P. ADAP2 in heart development: a candidate gene for the occurrence of cardiovascular malformations in NF1 microdeletion syndrome. J Med Genet. 2014;51:436-43.

13. Paul C, Sardet C, Fabbrizio E. The histone- and PRM5-associated protein COPR5 is required for myogenic differentiation. 2012. Cell Death Differ. 2012;19(5):900-8.

14. Stopa N, Krebs JE, Shechter D. The PRMT5 arginine methyltransferase: many roles in development, cancer and beyond. Cell Mol Life Sci. 2015; 72:2041-59.

15. Pasmant E, Sabbagh A, Spurlock G, Laurendeau I, Grillo E, Hamel MJ, Martin L, Barbarot S, Leheup B, Rodriguez D, Lacombe D, Dollfus H, Pasquier L, Isidor B, Ferkal S, Soulier J, Sanson M, Dieux-Coeslier A, Bièche I, Parfait B, Vivaud $M$, Wolkenstein $P$, Upadhyaya M, Vidaud $D$, and the members of the NF France Network. NF1 microdeletions in Neurofibromatosis Type 1: from genotype to phenotype. Hum Mutat. 2010;Mutation in brief 31:E1506-E1516.

16. Alkindy A, Chuzhanova N, Kini U, Cooper DN, Upadhyaya M. Genotypephenotype associations in neurofibromatosis type 1 (NF1): an increased risk of tumor complications in patients with NF1 splice-site mutations? Hum Genomics. 2012:6:12

17. Viaggi CD, Cavani S, Pierluigi M, Antona V, Piro E, Corsello G, Mogni M, Piccione M, Malacarne M. Characterization of a complex rearrangement involving chromosomes 1, 4 and 8 by FISH and array-CGH. J Appl Genet. 2012;53(3):285-8.

\section{Publisher's Note}

Springer Nature remains neutral with regard to jurisdictional claims in published maps and institutional affiliations.

\section{Ready to submit your research? Choose BMC and benefit from:}

- fast, convenient online submission

- thorough peer review by experienced researchers in your field

- rapid publication on acceptance

- support for research data, including large and complex data types

- gold Open Access which fosters wider collaboration and increased citations

- maximum visibility for your research: over $100 \mathrm{M}$ website views per year

At BMC, research is always in progress.

Learn more biomedcentral.com/submissions 